\title{
Review of Open Access Papers for Eruption Crisis in Puna (Big Island of Hawai'i)
}

\author{
Bulletin of Volcanology Editor-in-Chief ${ }^{1}$
}

Published online: 21 June 2018

(C) Springer-Verlag GmbH Germany, part of Springer Nature 2018

Due to the current eruption crisis at Kilauea volcano, where eruptive fissures have opened up in residential areas of Puna, the Bulletin of Volcanology has opened access to six scientific papers that provide insight into past volcanic activity in Puna, and set the context of current societal hazard.

Two papers deal with volcanic hazard in Puna: aka the Lower East Rift Zone (LERZ) of Kilauea. Richard Moore carried out detailed mapping of lava flows covering Puna and discovered that at least 112 eruptions had occurred during the past 2360 years. Lava of $200-400$ years old covers $50 \%$ of the area, and lava younger than 200 years old covers $25 \%$ of the area. Moore thus stresses,

I describe the volcanic hazards in the area, partly because commercial and residential development on and near the LERZ continues almost unabated.

Instead, David Clague and colleagues focused on a single eruption that occurred around A.D. 1445 and whose lavas invaded large parts of Puna. The eruption lasted around 50 years and built a $430-\mathrm{km}^{2}$ lava flow field that stretched $40 \mathrm{~km}$ from Kilauea's summit to the coast, and which — today - underlies several sub-divisions. Clague and colleagues thus stressed a specific type of hazard: that resulting from a long-lived eruption of lava from the volcano summit that slowly buries a large area.

The second set of papers details the 1955 and 1960 eruptions of Kilauea that opened up from fissures close to the current site of activity in Puna. Gordon Macdonald describes

Bulletin of Volcanology Editor-in-Chief andrew.harris@uca.fr

1 Bulletin of Volcanology Editorial Office, Laboratoire Magmas et Volcans, Université Clermont Auvergne, Aubière,

Clermont-Ferrand, France the 1960 eruption which, like the current event, erupted moreor-less inside a town, this being the town of Kapoho. Kapoho was, eventually, totally destroyed, but Macdonald documents the attempts to build barriers so as to delay the ingress of lava into the vulnerable community. Ritchie Hoe and Michael Garcia instead focus on the eruption dynamics of the 1955 eruption. Applying chemical analyses, they found that a dike was intruded $15 \mathrm{~km}$ down the rift zone (that connects Puna to the summit of Kilauea) eight days after the eruption began. This forced magma already in the rift zone to be pushed out onto the surface, so that they concluded:

"the dike probably acted as a hydraulic plunger forcing more of the stored magma to be erupted"

The work of Rosalind Helz and Thomas Wright confirmed that the character of the 1955 lava was consistent with a source that had spent some time sitting in the rift zone - cooling and crystallizing - before being pushed out by the magma that moved from the summit down the rift and into Puna. The work of Michael Garcia and colleagues finishes by showing how the opening phase of the current eruption (of which the Puna event is a part) also began by pushing out rift-zone-stored magma - erupting (on 3 January 1983) magmas that had been sitting in the rift zone since 1977.

Founded in 1922, the Bulletin of Volcanology is the official journal of the International Association of Volcanology \& Chemistry of the Earth's Interior (IAVCEI). The Bulletin publishes papers on volcanoes, their products, their eruptive behavior, and their hazards (https://link.springer.com/journal/445).

Open access to the six papers released here can be found at:

- Hazard in Puna

- Moore (1992) Volcanic geology and eruption frequency, lower east rift zone of Kilauea volcano, Hawaii. Link https://link.springer.com/article/10.1007/BF00301393 
- Clague et al. (1999). Kīlauea summit overflows: their ages and distribution in the Puna District, Hawai'i. Link https://link.springer.com/article/10.1007/s004450050279

- The 1955 and 1960 eruptions in Puna

- Macdonald G.A. (1962). The 1959 and 1960 eruptions of Kilauea volcano, Hawaii, and the construction of walls to restrict the spread of the lava flows. Link https://link. springer.com/article/10.1007\%2FBF02599351

- Ho \& Garcia (1988) Origin of differentiated lavas at Kilauea Volcano, Hawaii: Implications from the 1955 eruption. Link https://link.springer.com/article/10.1007/ BF01047507
- Helz \& Wright (1992). Differentiation and magma mixing on Kilauea's east rift zone: A further look at the eruptions of 1955 and 1960. Part 1. The late 1955 lavas. Link https://link.springer.com/article/10.1007/ BF00312319

- Rift-zone processes

- Garcia et al. (1989). Petrologic constraints on rift-zone processes: results from episode 1 of the Puu Oo eruption of Kilauea Volcano, Hawaii. Link https://link.springer. com/article/10.1007/BF00301548 